\title{
TRANSLATING THE HISTORICAL BOOKS
}

It is a well known fact that the translation of the Pentateuch is not always a faithful rendering of the original text, despite the affirmations to the contrary made by the author of the Letter of Aristeas §310: "Since this version has been made rightly and reverently, and in every respect accurately, it is good that this should remain exactly so, and that there should be no retouch." The discrepancies between the original and the Greek copies were noticed at an early stage; this is apparent in the quick response to correct the Greek with the relation to the Hebrew in the most ancient papyri, and the warning signs expressed by the translator of Sira in the Prologue, probably wishing to enter into a polemic with the author of the Letter of Aristeas: "For what was originally expressed in Hebrew does not have exactly the same sense when translated into another language. Not only that, but even the Law itself, the Prophecies, and the rest of the books differ not a little when read in the original”. Even in the Pentateuch there are important discrepancies between the Greek and the Hebrew such as Jacob's blessings (Gen 49), the account of the Tabernacle (Ex 35-40), Balaam's oracles (Num 22-24) or the Song of Moses (Dt 32).

However, when we move beyond the Pentateuch to the new corpus of the Historical books (the former Prophets in the Hebrew Scriptures) these differences between the Greek and the Hebrew Bible are more common and widespread. I do not mean the differences that arise from the contact between languages in the process of translation, but the focus on the major discrepancies which, can we say, make the Greek Bible another Bible, the Bible of Hellenistic Jews, just as the members of the community of the Judean Desert had their own Bible, the Bible of Qumran. Those changes affect: a) the organization of the material; b) the inclusion of new books, or supplements to some books, which are lacking in the Hebrew Bible; c) the presence of double text for some of the Greek books, and d) the appearance of early revisions in some of these books which notably modify the history of text transmission. These transformations emphasize the many voices of the Biblical text in Greek, the richness and originality of the Greek Bible as a literary and autonomous work.

To begin with, the book of Ruth, which in the Hebrew Bible counts among the Megilloth, in the Septuagint is placed after Judges as the last book of the Octateuch, no doubt following the chronological suggestion of the first words of the book: "In the days when the judges ruled..." 1-2 Paralipomena and 1-2 Ezra follow 1-4 Kings. In addition, 
new books, not included in the Hebrew Scriptures, are produced, books such as Judith, Tobit and 1-4 Maccabees; or supplements are attached to some Hebrew books, for example, the six supplements to Esther or the story of the three bodyguards in 1 Ezra (1 Ezra 3-5:6).

All these additions or new productions were considered to have a certain connection with the historical books. In other words, the Former Prophets of the Hebrew Bible have not only been translated but also transformed and completed with new stories which extend to the history of Israel at their own time, or with fictitious stories on the way Jews should behave in conflict with their religious beliefs in the hostile milieu of the diaspora, or novels on Jews in the court of a foreign king.

Concerning the double texts in Greek it is worth emphasizing that Rahlfs' manual edition prints the book of Judges in two recensions: the text of codex Alexandrinus and its group, and the text of the Vaticanus in the upper and lower part of the page respectively, apparently considering them, in line with P. A. de Lagarde, as two different translations. The same could be said for some chapters of Joshua, printed by Rahlfs in parallel columns (Jos 15:21-62 and 18:22-19:45). For the time being, although the Greek manuscripts have already been collated in the SeptuagintaUnternehmen of Göttingen, these books lack a critical edition in order to stratify the evidence of the manuscript tradition and restore, in all probability, a single archetype.

But even some books critically edited in the series maior of Göttingen attest phenomena of double recensions. The Greek Esther, according to the critical edition of R. Hanhart, has been transmitted in two different forms: the o' text and the $L$ or Alpha text, which cannot be traced back to a single archetype. The relationship between both recensions and the original Hebrew is the object of strong debate among the experts of the Septuagint. The book of Tobit exists in two (and partially three) different textual forms: a long text attested mainly by codex Sinaiticus and the Vetus Latina, and a short text attested by codices Alexandrinus, Vaticanus and the most part of the Greek tradition; two textual forms which cannot be genetically reduced to a single original.

In brief, the polyphonic character of the Greek Bible becomes patent once we cross the frontier of the Pentateuch. It is possible that when they were being translated those books were not considered as authoritative as the Torah, and it was this that allowed the translators to also be creative scribes intervening with more freedom on the original text or creating new writings in response to the needs of the community. 
The text history and transmission of the books of Kings is peculiar in many aspects. The Old Greek of the story of David and Goliath (1 Kings 17-18:5) reflects a short version with 31 verses less than the Masoretic text; in 3 Kings 2-14 the divergences between the Old Greek and the Hebrew are so strong that this narrative probably offers two different versions of Solomon's access to the throne. Moreover, in some parts of the historical books, the so-called kaige sections of Kings (2 Kings 11:23 Kings 2:11, and 3 Kings 22-4 Kings), the mainstream Greek tradition transmits a revised text, while the Antiochene text escaped this Hebraising revision, and is homogeneous throughout 1-4 Kings, and closer to the Old Greek.

To cope with these problems modern translations have had recourse to different procedures: La Bible d'Alexandrie, on the base of Rahlfs' edition, translates the short text of David and Goliath's story in 1 Kings 17-18:5 and inserts, in italics within the current text, the long text printed by Rahlfs in the apparatus. The New English Translation of the Septuagint (NETS) simply translates the short text, supposed to be the Old Greek. The Septuaginta-Deutsch (LXX-De), however, translates the short text and inserts into the current text the translation of the long text between asterisk and metobelus, to indicate that it has been transmitted by the Hexaplaric recension, although it is also attested by the Antiochene manuscripts.

As for the kaige sections, I am not aware of the policy to be followed by $L a$ Bible d'Alexandrie, since only 1 Kings has been published up to now. NETS follows Rahlfs' edition in Kings, in spite of being a composite text of Old Greek plus the Hebraising revision. However, both sections are translated by different scholars, B. A. Taylor for the Old Greek and P. D. McLean for the kaige sections. A third solution has been adopted by the translators of LXX-D (S. Kreuzer et al). They usually follow the text of Rahlfs' edition but in the kaige sections they translate in parallel columns Rahlfs' text and the Antiochene text according to the critical edition of the Madrid team.

I have the impression that these compromise solutions do not satisfy the requirements of the present state of Septuagint research. Rahlfs' manual edition is not only a composite text of Old Greek plus a late revised text. Influenced by his negative judgement on the Lucianic recension, which he considered both late and of secondary character, Rahlfs usually does not take into account the readings of the Lucianic group of manuscripts, as stated in a note to the apparatus at the beginning of Kings: Huius editionis [that is, the Lucianic] innumeras lectiones singulares (cf. Rahlfs Sept.-Stud. 3 [1911]) praetereo. 
As we started working on the translation of the historical books we thought that the Spanish translation could be a new contribution to the map of modern translations focusing exclusively on the version of the current Antiochene text.

The choice was taken to translate 1-4 Kings and 1-2 Paralipomena on the base of the Antiochene text edited in Madrid. First of all, it is a current, homogeneous text throughout 1-4 Kings which, in general, preserves an ancient text very close to the Old Greek. Nowadays, in contrast to Rahlfs' devaluation of the Antiochene or Lucianic text, a revaluation can be perceived, as far as it is a text attested by a group of minuscules since the 9th century, but which can be traced back to the fifth century in Theodoret's quotations, back to the second century by the agreements of Antiochene with Josephus and the Vetus Latina, and to the first century CE by its agreements with 4 QSam ${ }^{\mathrm{a}, \mathrm{c}}$. It has been selected as the base of the Spanish translation due to the inner quality and antiquity of most of its readings and to the genuine character of these sections of the Greek tradition that escaped the kaige revision. Among other literary and editorial divergences, with relation to the majority text of the Septuagint, there is one which is worth emphasizing: the prolongation of the second book of Kings to 3 Kings 2:11, the death of David, in parallel with 1 Kings which ends with the death of Saul; and the beginning of 3 Kings in 3 Kings 2:12, with the reign of Solomon.

This text was held in high esteem by Julius Wellhausen in the 19th century, because the Lucianic manuscripts in 1-2 Kings not only often confirmed his critical decisions but also backed up his own conjectures ${ }^{1}$. Moreover, Thackeray, at the beginning of the 20th century, was already putting forward some of the reforms of the Greek text of 1-4 Kings that have been adopted in our edition of the Antiochene text: "It will probably not fall within the scope of the larger Cambridge Septuagint to depart from the arrangement of books in the Codex Vaticanus, but I venture to think that in the Septuagint of the future the second of the four Kingdoms books will end with the death of David." ${ }^{2}$

In order to navigate safely and soundly through the complex history of the biblical text in the historical books one should be aware that in several of these books two textual stages, chronologically differentiated, can be detected: a) the Old Greek or first translation on the one side, and b) a Hebraising revision on the other, the so-called kaivge revision, with its starting point in the first century BCE. The aim of this

\footnotetext{
${ }^{1}$ J. Wellhausen, Der Text der Bücher Samuelis, Göttingen: Vandenhoeck \& Ruprecht 1871, p. 223.

${ }^{2}$ H. St. J. Thackeray, "The Greek Translators of the Four books of Kings," JTS 8 (1907) 262-278, p. 266.
} 
revision was to approximate the Old Greek version to the Proto-Masoretic Hebrew which started to be predominant within Judaism. The book where these two stages are most visible is Judges, edited by Rahlfs in a double text, the A-text and the B-text. The second, the text of Vaticanus, Sinaiticus and a group of minuscules transmits a late Hebraising, the so-called kaige revision. At the other extreme of this translation process, one comes across the book of Ruth, a very literal version according to the ProtoMasoretic text. There is not an Old Greek of Ruth, because the translation was probably carried out by a member of the kaige group in the first century CE.

In the books of Kings both stages can be detected: the Old Greek represented mainly by the Antiochene text throughout all the books, joined to the majority text in the non-kaige sections, and the kaige revision of the majority text in the kaige sections. In Judges, Rahlfs offered a critical text based mainly on codex Alexandrinus and the Hexaplaric and Lucianic recensions; it was clear to him that the text of Vaticanus did not represent the Old Greek in this book. However, in the books of Kings Rahfs opted basically for the Vaticanus as the basis of his edition, relying on his research on the Lucianic text published in $1911 .^{3}$

According to some recent studies by Böhler, the same scheme could be applied to 1-2 Ezra: 1 Ezra would correspond to a fairly free translation of the Old Greek, including material which is not to be found in the Hebrew Bible such as the three bodyguards of king Darius; and in a second stage with 2 Ezra, a more literal Hebraising translation of the Hebrew Ezra-Nehemiah ${ }^{4}$.

To return to the Antiochene text in the books of Kings, I think that our option is, for the moment, the best solution while waiting for the critical editions of Joshua, Judges and the rest of the historical books in the Göttingen series. The Antiochene text is first and foremost Septuagint, that is to say that the great number of coincidences with the majority Greek text is such that it represents the same current of tradition as the Old Greek. It shares with the rest of the Septuagint the additions of 3 Kings 2:35a-o and 46a-l on the wisdom and prosperity of Solomon, as well as 3 Kings 12:24a-z; all of these passages do not have their equivalent in the Masoretic Hebrew. It also shares with the rest of the Septuagint the distinctive organization of the material in 3 Kings as well

\footnotetext{
${ }^{3}$ A. Rahlfs, Lucians recension der Königsbücher. Septuagintastudien III, Göttingen: Vandenhoeck \& Ruprecht 1911.

${ }^{4}$ D. Böhler, Die heilige Stadt in Esdras a und Esra-Nehemia: zwei Konzeptionen der Wiederherstellung Israels. OBO 158, Fribourg/Göttingen: Presses universitaires/Vandenhoeck \& Ruprecht 1997. For another view that 1 Ezra is a subsequent composition depending upon the biblical books see Z. Talshir, $I$ Esdras: From Origin to Translation. SBLSCS 47, Atlanta: SBL 1999.
} 
as the permutation of chapters 20 and $21^{5}$. In other words, it is not a new translation from the Hebrew, or 'an Old Greek' ${ }^{6}$, as if there had been another translation. It develops in the mainstream of the Old Greek, nevertheless it departed from the majority current of LXX at an early stage, probably in the first century CE, and its transmission was relatively independent from the rest of the Greek tradition ${ }^{7}$. This explains the considerable number of original readings it conserves and which were lost in the rest of the manuscript tradition. The proper names merit our special attention; their forms differ considerably from those transmitted by the rest of the Septuagint, the Hexaplaric recension included, and reproduce more faithfully the forms of a Hebrew older than the Masoretic text. For instance, in 2 Kings 9 the son of Jonathan and Saul's grandson preserves in Antiochene the original name Memfibaval, corrected to Memfibovsqe in the majority text of the Septuagint according to the Masoretic Text which substituted the ancient name of the god Baal by the derogatory designation of $t \# b$, "shame."

Nevertheless I do not think that the Antiochene text can be identified with the Old Greek. Some elements of a stylistic recension can be detected even at an early stage $^{8}$. The Old Greek can only be restored through the comparison of all the witnesses and the elimination of the recensional features in the diverse groups of manuscripts. As Aejmelaeus says: "Sie [The Old Greek] hat die Vorlage sowohl für die lukianische wie für die Kaige-Rezension gebildet und kann aufgrund der beiden wiederhergestellt werden, wenn die Rezensionszüge der beiden Rezensionen erkannt werden. Praktisch würde ich here den Hinweis geben neben Rahlfs die spanische Edition des antiochenischen (d. h. lukianischen) Textes zu stellen. When eine Textstelle zugleich in den beiden verschiedenen Rezensionen geändert worden ist, dann bleibt nur die Rekonstruktion des ursprünglichen Textes übrig 9 ." However, according to S. Kreuzer, in view of the agreements of Antiochene with Josephus, Vetus Latina, probably the

\footnotetext{
${ }^{5}$ In accordance with these data, 3 Kings would end in the Vorlage of the Septuagint in chapter 21, the victory of Ahab ( = chapter 20 of the MT), and 4 Kings would begin in chapter 22 of 3 Kings. Thackeray is also inclined to place the end of the third book of Kings at the end of chapter 21 of the Septuagint, cf. H. St. J. Thackeray, The Septuagint and Jewish Worship. A Study in Origins, London 1923², p. 19.

${ }^{6}$ See note 16.

7 S. P. Brock, "A Doublet and its Ramifications", Biblica 56 (1975) 550-553, p. 553.

${ }^{8}$ S. P. Brock, "Lucian redivivus. Some Reflections on Barthélemy's Les Devanciers d'Aquila", in Studia Evangelica V, edited by F. L. Cross, Berlin: Akademie-Veerlag 1968, 176-181.

${ }^{9}$ A. Aejmelaeus, "Die Übersetzung einer Übersetzung. Vom Hebräischen über das Griechische in eine moderne Sprache", in S. Kreuzer-J. P. Lesch (eds.) Im Brennpunkt: Die Septuaginta. Studien zur Entstehung und Bedeutung der Griechischen Bibel. Band 2, BWANT 161, Stuttgart: Kohlhammer 2004, 133-150, pp. 136-137.
} 
New Testament, ${ }^{10}$ and Qumran, the analysis in Kings must be inverted: Antiochene is a uniform and homogeneous text, close to the features of the Old Greek, but without excluding the existence of a slight proto-Lucianic and a late Lucianic revision. In contrast, it is the Vaticanus and the kaige revision which changed the text in Kings more radically, according to the new fashion of accommodating the biblical texts to the dominant Proto-Masoretic Hebrew ${ }^{11}$. Kim Jong-Hoon comes to similar conclusions in his doctoral dissertation ${ }^{12}$, that most of the differences between kaige and Antiochene in Kings are explained by the style and grammar of the original Greek language, maintained in Antiochene, and corrected in kaige towards a strict literalism ${ }^{13}$.

Notwithstanding I would like to point out that the passages analyzed by Kreuzer and Jong-Hoon belong exclusively to the kaige sections, and that the analysis should be extended also to the non-kaige sections in order to verify in which direction the correction goes in those cases where there are discrepancies between the Vaticanus and the Antiochene. I think that the Old Greek in Kings is still a vanishing ideal only attainable through a rigorous application of textual criticism to the main recensions or groups of texts identified according to the procedure used by the Göttingen series. That is, each variant has to be weighed on a case-by-case basis.

Our option of translating the Antiochene text is a compromise solution while waiting for the standard critical edition. I am aware of the shortcomings of this version of a text which cannot be identified with the Old Greek. But at least it is a real text read in the first centuries CE in the patriarchate of Antioch. The difficulty to distinguish between the final stage of the recension and the Proto-Lucianic material does not prevent it from being readable and understood. The frequent presence of doublets or alternative readings, which may go back to Hebrew sources, means that hardly an old variant has been excluded. It is an expansive text concerned with the completion of what was implicit in the different moments of the narrative according to the scheme of announcement and fulfilment; the insertion of short phrases to clarify any uncertain

\footnotetext{
${ }^{10}$ See Rom 11:3-4.

${ }^{11}$ S. Kreuzer, "Towards the Old Greek: New Criteria for the Analysis of the Recensions of the Septuagint (Especially the Antiochene/Lucianic Text and Kaige Recension)", in XIII Congress of the International Organization for Septuagint and Cognate Studies, Ljubljana, 2007, Atlanta: Society of Biblical Literature 2008, 239-253, p. 253, and ----, "Translation and Recensions: Old Greek, Kaige, and Antiochene Text in Samuel and Reigns", BIOSCS 42 (2009) 34-51.

${ }^{12}$ Kim Jong-Hoon, Die hebräischen und griechischen Textformen der Samuel- und Königsbücher. Studien zur Textgeschichte ausgehend von 2Sam 15,1-19,9. BZAW 394. Berlín/New York, Walter de Gruyter 2009.

${ }^{13}$ Against Rahlfs' interpretation who attributed the Antiochene readings to scholarly corrections,

"Gelehrten korrekturen". See note 3, p. 283.
} 
situation and soften the passage of any breaks in meaning. The reworking of style on certain occasions, including multiple changes in the hyperbaton of the sentence, is a sign that the addressees were seriously taken into account. In short, it seems to be a text "designed for public reading," 14 a text that can be read and understood quite well. Early authors and modern commentators emphasize the capacity of the Antiochene recension to put the materials in their right place and to reorganise the narrative. There are no gaps in the sequence throughout 1-4 Kings; it includes even the long text of David and Goliath.

Our aim is to offer a faithful translation of this current text without signalling graphically its deviations from the Hebrew, convinced that these discrepancies are not only quantitative (additions and omissions) but permeate the whole structure of the translation, shifting and rearranging the material, and qualitative modifications inasmuch as the first translation is, at the same time, the first interpretation of the Hebrew Bible. I would like to emphasize its most important intervention, the prolongation of the second book of Kings to 3 Kings 2,11. It would have been difficult to achieve this unless it could be born out by the same sequence of material in the Hebrew scrolls used as the basis of the translation. We have no documentary proof of the existence of ancient Hebrew scrolls or codices with the same distribution of material. There are, however, other indications which support this hypothesis. The kaige revision, in section bg, ends precisely where 2 Kings ends in the Antiochene text, in 3 Kings 2,11.

There is, therefore, no need to enter into sophisticated speculations as to the motives for this revision and why it only covers two concrete sections of the books of Kings. I share Barthélemy's view that the kaige revision originally encompassed the whole of the books of Kings, and that the fact that only two sections remain corrected is due to an accident of transmission, the alternate copying of different types of scrolls by the scribe of the archetype of the Vatican codex. This resulted in a mixed text, alternating sections from the Old Greek type with sections from the kaige type ${ }^{15}$. Both, the kaige revision and the Antiochene text belong to a period in which the biblical text was transmitted in scrolls and not in codices. Therefore, the value of the Antiochene text

\footnotetext{
${ }^{14}$ S. P. Brock, The Recension of the SeptuagintVersion of I Samuel, Torino: Silvio Zamorani 1996, p. 252.

${ }^{15}$ D. Barthélemy, Études d'histoire du texte de l'Ancien Testament. OBO 21. Fribourg/Göttingen: Éditions universitaires/Vandenhoeck \& Ruprecht 1978, p. 275.
} 
in the books of Kings lies in the fact that it transmits a homogeneous text which has not undergone the Hebraising revision.

But I do not pretend that we are offering a translation of the Old Greek; this was lost for all the books. The Old Greek can only be reached through the examination of all the evidence at our disposal submitted to the rules of textual criticism. Certainly I do not think that in the non-kaige sections the substratum of the Antiochene text always represents the Old Greek ${ }^{16}$. The linguistic and literary traits which appear in the Antiochene text cannot be identified with the characteristics of the Old Greek nor can they be the mere product of historical evolution ${ }^{17}$. The specific differences between Antiochene and the text of Vaticanus that still remain precisely in the non-kaige sections necessitate some explanation. Both, Antiochene and Vaticanus, cannot be Old Greek And it is more plausible to explain these differences as a slight revision of Antiochene than the other way around, from Antiochene as the Old Greek to move towards the text of Vaticanus.

Moreover, the changes in Antiochene can be explained as being the result of an editorial intervention whose purpose was to eliminate some, but not all, of the most obvious Hellenistic Greek forms and substitute them for the Attic forms. We do not know whether the purpose of these changes was to adapt the text for public reading, to serve the needs of the community or more simply to accommodate it to the literary tastes of the times. In any case these changes cannot be compared with the systematic and radical elimination of the historic present by the kaige revision. Of special interest is the high number of lexical variants, as pointed out in the Greek-Hebrew Index published by our team ${ }^{18}$; these variants merit careful study in the light of the Atticistic lexica, in order to ascertain the possible reasons for the change and appreciate the character of the copyists who were acting, to a large extent, as authors.

\footnotetext{
${ }^{16}$ Contrary to the view of Tov who states: "In conclusion, it is suggested here that the substratum of boc $_{2} \mathrm{e}_{2}$ contains either the OG translation or any single OG translation," cf. E. Tov, "Lucian and ProtoLucian. Toward a New Solution of the Problem," RB 79 (1972) 101-113, now in E. Tov, The Greek and Hebrew Bible. Collected Essays on the Septuagint. VTS 72, Leiden/Boston/Köln: Brill 1999, 477-488, p. 484.

${ }^{17}$ See S. Kreuzer, "Translation and Recensions", p. 44: " Be it unintentional mistakes and corruptions only, or be it a minor revision, the Antiochene text represents the OG"; and D. Barthélemy, Les Devanciers d'Aquila. VTS 10, Leiden: Brill 1963, p. 127.

${ }^{18}$ N. Fernández Marcos, M ${ }^{\mathrm{a}} \mathrm{V}^{\mathrm{a}}$ Spottorno Diaz-Caro y J. M. Cañas Reíllo, Índice griego-hebreo del texto antioqueno en los libros históricos. Volumen I: Índice general, Madrid: CSIC 2005; Volumen II: Índice de nombres propios, Madrid: CSIC 2005.
} 
Other features of the Antiochene text have been summarised by S. Brock ${ }^{19}$, such as the preference for the second aorists, the tendency to eliminate the Semitism of the translation: the beginnings with eij in the oaths are substituted by oujk; the Hebrew expression ejrwta'n eij" eijrhvnhn, is sometimes substituted for the more classical ajspavsasqai ... ejn eijrhvnh/. It is common to write the verb in the singular with the neuter plural subject and the article is frequently included although it is absent in the Hebrew. More use is made of participles to avoid the paratactic constructions, and there is a greater variety in the use of particles. Transliterations tend to be discarded and replaced by translations. Indeed, the question must remain open as to whether all these characteristics belong to the Antiochene revision or go back to the style and characteristics of the Old Greek in Kings. But in any event, these are characteristics which are not shared by Vaticanus in the non-kaige sections.

I have insisted on the fact that the Antiochene text is above all Septuagint, that it shares, together with the rest of the Greek tradition, the major part of the differences compared with the Masoretic text, in particular 3 Kings 12-14. Even in those sections where the differences between the Antiochene and the rest of the Septuagint are not so obvious, the basic coincidence is confirmed ${ }^{20}$. There are also a number of literary and editorial features which I have described elsewhere ${ }^{21}$. The role of this editorial activity was, in part, to produce a more harmonious narrative, rounding off the rough edges so that it flowed more smoothly.

Stratifying these types of interventions chronologically is no easy task and continues to provide fodder for scientific debate. Pisano maintains that one of these tendencies, that of completing what was left unsaid or half unsaid in the original, had already started with the very translation of the Old Greek of 1-2 Kings or even in its Hebrew Vorlage, if we compare it with the character of the Masoretic text ${ }^{22}$. If this were the case, certain of these features would date back to the Old Greek or its base Hebrew text. Clarification and search for meaning is at the base of every process of translation.

\footnotetext{
19 S. P. Brock, The Recensions, pp. 252-253.

20 "As far as $1 \mathrm{Kms}$ is concerned, the matter in common between $\mathrm{L}$ and LXX rell is so great that it would have required a Philonic miracle (and then not a very competent one, in view of the actual divergencies) to have brought about such a close identity of two different translations," cf. S. P. Brock, The Recensions, p. 31.

${ }^{21}$ N. Fernández Marcos, "Literary and Editorial Features of the Antiochian Text in Kings", in C. Cox (ed.), VI Congress of the International Organization for Septuagint and Cognate Studies, Jerusalem 1986, Atlanta GA: Scholars Press 1987, 287-304.

${ }^{22}$ S. Pisano, Additions or Omissions in the Books of Samuel. OBO 57. Fribourg/Göttingen: Éditions universitaires/Vandenhoeck \& Ruprecht 1984, pp. 67-69 and 238-242.
} 
However, the level reached in the Antiochene text is far superior to anything that can be found in the tradition of the Septuagint. That is why I maintain that Antiochene is to a large extent (though not wholly) the result of recensional and editorial activity. But I am rather inclined to admit that there are older recensional elements - which include stylistic improvements and a few non-Hexaplaric approximations to the Hebrew- and, of course, a collection of ancient, in all probability, original readings. These composite elements of the recension prevent me from identifying the simple characteristics of the Antiochene recension with the characteristics of the Old Greek in Kings. To separate the late features of the recension from the Proto-Lucianic component is one of the most difficult problems of Septuagint research in $\mathrm{Kings}^{23}$. I would also add, modifying Wevers' statement, that to separate the Proto-Lucianic component from the Old Greek is even more difficult.

The connection between $4 \mathrm{QSam}{ }^{\mathrm{a}}$ and the Hebrew Vorlage of the Old Greek would seem to have been proved, although insufficient evidence was found to affirm any link between Antiochene and 4QSam ${ }^{\mathrm{a}}$, except for Antiochene's dependence upon LXX, which was in turn dependent upon 4 QSam ${ }^{\mathrm{a} 24}$. But to whatever extent the documents of Qumran have confirmed the faithful nature of the Septuagint as a testimony of the Hebrew Vorlage, the Septuagint is also interpretation. In other words, the Septuagint does not transmit the biblical text as just another copyist, but rather as an interpres, and in this context there is a greater margin for the inclusion of ideological variants, even though they may have been introduced unconsciously. In the original it is quite possible to copy passages which have been corrupted or which are totally incomprehensible. But, in translation, it is not plausible to present an incomprehensible text.

Some years ago Prof. Marguerite Harl reminded her Spanish colleagues that it would be desirable to provide the Antiochene text edited in Madrid with a modern translation. That is precisely what we have tried to do with this new version into Spanish of the Antiochene text, the first complete translation into a modern language. It is a complete text, which provides meaning and clarification even for those passages which are obscure or ambiguous in the original, a text for public reading. With this

\footnotetext{
${ }^{23}$ "All in all, the so-called proto-Lucianic text is to my mind the most difficult problem in modern Septuagint work," see J. W. Wevers, "Proto-Septuagint Studies", in The Seed of Wisdom. Essays in honor of T. J. Meek, W. S. McCullough (ed.), Toronto: Toronto University Press 1964, 58-77, p. 69.

${ }^{24}$ H. D. Herbert, "4QSam ${ }^{a}$ and its Relationship to the LXX: an Exploration in Stemmatological Analysis", in IX Congress of the International Organization for Septuagint andf Cognate Studies, Cambridge 1995, B. A. Taylor (ed.), SCS 45, Atlanta GA 1997, 37-55, p. 49.
} 
translation we hope to offer not only a service to the Spanish-speaking community but also to provide a contribution to the studies of the Septuagint.

There still remain many problems which require appropriate solutions. The debate will continue on the complicated text history in Kings, on the relationship between the Old Greek and Antiochene in the non-kaige sections, trying to guess who corrected whom and which is the secondary text, the one which allows facilitation and harmonization in relation to the other. But for the time being, I think that the option of translating the Antiochene text, whose quality in the historical books has been sufficiently proved, is not only plausible but fully justified.

Natalio Fernández Marcos

Centro de Ciencias Humanas y Sociales. CSIC

Albasanz, 26-28

28037 MADRID (Spain)

natalio.fernandez@cchs.csic.es 